\title{
The frequency of shiga-like toxin (stx1 and stx2) and EHEC-hly $A$ in food by multiplex PCR
}

\author{
Cansu Onlen, Nizami Duran*, Suphi Bayraktar, Emrah Ay, Burçin Ozer
}

Mustafa Kemal University, Medical Faculty, Department of Medical Microbiology, Hatay, Turkey

\begin{abstract}
Aim: The aim of the present study was to determine the frequency of shiga-like toxin (stx1 and stx2) and drug resistance profiles food-borne Escherichia coli O157:H7 in Hatay province, Turkey.

Methods: The presence of the virulence genes (stx1, stx2, hlyA) in a total of 150 E.coli isolates were studied with multiplex PCR.

Results: A total of 327 salad samples were analyzed. E. coli O157:H7 was detected in 150 (45.8\%) out of 327 analyzed samples. Of these 150 isolates, the presence of hly-A gene was detected in $32(21.3 \%)$ E.coli isolates. A total of five (15.6\%) isolates in this 32 hlyA positive isolates had stx2 gene, two (6.3\%) of them had stxl gene and one (3.1\%) of the isolates was found to be positive for both stxl and stx2 genes. It was found that all E.coli O157:H7 isolates were resistant to erythromycin. While the highest rate of antibiotic resistance was observed for ampicillin (68.8\%), no antibiotic resistance against cefuroxime, ciprofloxacin and cephaperasone was identified.

Conclusions: The results obtained in our province showed that E.coli strains isolated from salad samples were found to have some important virulence genes such as stx1, stx2, and hlyA. The stx2 frequency was found to be higher than stxl frequency. Also, it was observed that there was not any significant correlation between drug resistance profiles and presence of toxin genes in E.coli O157:H7 strains. As a result, increasing frequency of STEC O157 serotype among foodborne pathogens is a growing public health problem.
\end{abstract}

Keywords: E.coli O157:H7, stx1, stx2, hly-A, PCR

Received: $2^{\text {nd }}$ March 2017; Accepted: $2^{\text {nd }}$ July 2017; Published: $17^{\text {th }}$ July 2017

\section{Introduction}

A significant part of salad microflora is composed of members of Enterobacteriaceae family. It is reported that the number of coliform bacteria in salads may reach $10^{5} / \mathrm{g}$. Particularly, E.coli is one of the most isolated bacteria in salads (1-4).
E.coli shows many different serotypes and of these serotypes, E.coli O157:H7 is a significant morbidity and mortality cause for human health. Bacteria enterohemolysin $(h l y A)$ and cytotoxin known as shiga toxin are important virulence factors (5). Enterohemolysin is coded by hly $A$ and causes lysis of erythrocytes, contributes to

*Corresponding author: Nizami Duran, Mustafa Kemal University, Medical Faculty, Department of Medical Microbiology, Hatay, Türkiye, e-mail: nizamduran@hotmail.com 
virulence of microorganisms and thus provides iron sources to bacteria so that they can survive in the intestine. As for shiga toxins, they have the ability to inhibit host protein synthesis and may lead to eucaryotic cell injury and death (6).

Infections caused by E.coli O157:H7 serotype may range from mild infections such as watery diarrhea to diseases such as hemorrhagic colitis, hemolytic uremic syndrome (HUS) and thrombocytopenia. HUS is considered as the primary reason for acute renal insufficiency among children. The treatment of the disease includesf hemodialysis and supportive care only $(7,8)$.

It is reported that E.coli $\mathrm{O} 157: \mathrm{H} 7$ commonly colonize in the intestinal system of farm animals. In recent epidemiological studies, it is indicated that dairy cattle are primary carriers of E.coli O157:H7 (9-11).

It is indicated that most of the E.coli O157:H7 infections may be associated with poorly cooked meat and dairy products, not-pasteurized products and vegetables contaminated with feces of these farm animals. Furthermore, it is pointed out that contamination risk by humans may be possible, too (12).

Because microorganisms exist in low quantities in contaminated food samples or feces samples, there may be problems and limitations in diagnosis using conventional methods. Although different methods such as culture tests and enzyme-linked immunosorbent assays (ELISA) have been used to detect bacteria, today molecular techniques based on polymerase chain reaction (PCR) are preferred for accurate and fast diagnosis of E.coli $\mathrm{O} 157: \mathrm{H} 7$ due to the problems related with practicabilities and sensitivities of these above mentioned methods $(13,14)$.

Following isolation of microorganisms, it is very important to demonstrate presence of virulence genes which are indicators of pathogenicity. Today; multiplex PCR are chosen most frequently for the diagnosis of important virulence genes such as E.coli $\mathrm{O} 157: \mathrm{H} 7$ shiga toxin-1 (Stx1), shiga toxin-2 (Stx2) and hlyA $(11,15)$. Food borne E.coli O157:H7 prevalence ranges from $0.8 \%$ to $22.5 \%$ in various studies conducted all over the World (14,15). In Turkey, there are studies that report that food borne E.coli $\mathrm{O} 157: \mathrm{H} 7$ prevalence ranges between $1 \%$ and $7.6 \%(15,16)$.

The aim of this study was to identify prevalence of E.coli $\mathrm{O} 157: \mathrm{H} 7$ in salad samples and presence of enterohemolysin $h l y A$, Stx- 1 and Stx-2 toxins in E.coli O157:H7 strains using multiplex PCR and to determine whether or not restaurants serving in Hatay Province (South of Turkey) are a potential threat to public health.

\section{Materials and Methods}

In the study, 327 salad samples taken from various restaurants and snack bars located in South of Turkey (Hatay Province) were included. According to Food Codex and Codex Alimentarius, 150 of 327 E.coli isolates were found to exceed the limit of pathogenity. These strains were examined (17).

These isolates were evaluated in terms of E.coli O157:H7 and presence of hly-A, stxl and stx 2 virulence factors. Salad samples of $250 \mathrm{gr}$. were collected in sterile containers by paying attention to aseptic conditions right after they had been prepared for service. Salad samples were thoroughly mixed before they were aseptically collected. Then, they were delivered to bacteriology laboratory through a cold chain. The samples were immediately homogenized and samples weighed as 1 gr. were added to the Mueller-Hinton Broth (Merck, Germany) for proliferation and incubated for 48 hours at $37^{\circ} \mathrm{C}$. Following the 48 hours of incubation; samples of $100 \mu \mathrm{l}$ were taken from the broth media using micropipettes and transferred into MacConkey or EMB (eosin methylene blue) agar. Plates were incubated for 48 hours at $37^{\circ} \mathrm{C}$ and analyzed. 


\section{Isolation and Identification}

Some inclusion and exclusion criteria have been taken into consideration in the identification of $E$. coli isolates. Inclusion criteria for $E$.coli isolates were growth on MacConkey or EMB agar medium (HiMedia, India) and complying with standard biochemical tests including triple sugar iron agar (TSI), sulfide indole motility (SIM), citrate agar, and methyl red voges-proskauer (MRVP), (18). The exclusion criteria were inhibition of growth on MacConkey or EMB agar medium and inconsistencies in the results of biochemical tests for E.coli.

Identification of the isolates was confirmed with Vitek-2 system (bioMerieux, France). E.coli isolates were kept at $-70{ }^{\circ} \mathrm{C}$ in broth containing $20 \%$ glycerol. Then, the collected samples in deep freeze were inoculated on sorbitol-MacConkey (SMAC) agar. After at least 24 hours of incubation at $37^{\circ} \mathrm{C}$, sorbitol-negative colonies were identified as $\mathrm{O} 157: \mathrm{H} 7$ isolates. All sorbitol-negative isolates were confirmed by $\mathrm{O} 157$ antisera (Difco Laboratories).

\section{DNA Extraction and Multiplex PCR}

For the genomic DNA extraction, commercially available GF-1 Bacterial DNA Extraction Kit (Vivantis, US) was used.

Using $h l y A, s t x-1$, stx-2 primers extracted from DNA samples; PCR amplifications were performed in a thermal cycler (Table I). The PCR amplification was carried out in a total volume of $25 \mu 1$. The PCR mixture was constructed as follows: $2.5 \mu 1$ PCR buffer (1x without $\mathrm{MgCI}_{2}$, $4 \mu 1 \mathrm{MgCl}_{2}(25 \mathrm{mM}), 1 \mu \mathrm{dNTP}(200 \mu \mathrm{M}$ each nucleotites), each primers (both $s t x-1$ and $s t x-2$ and $h l y A$ genes), Taq DNA polymerase $0.5 \mu 1$ $\mathrm{U}(5 \mathrm{U} / \mu \mathrm{l})$, template DNA $1 \mu \mathrm{l}$ (approximately $50 \mathrm{ng}$ ). The $h l y A$ gene was amplified in a single PCR reaction in one tube. The PCR mixture was exactly the same as indicated above for $s t x-1$ and $s t x-2$ genes.

In the current study; Escherichia coli O157: H7 ATCC 43888 was used as negative standard strain while ATCC 43895 (positive for stx- 1 and $s t x-2$ genes) and ATCC 43889 (negative for $s t x-$ 1 , positive for $s t x-2$ ) were used as positive standard strain.

Standard strains were obtained from Istanbul University, Department of Pharmaceutic Microbiology of The Faculty of Pharmacy and Cukurova University, Central Laboratory Culture Collection of Medicine Faculty.

The PCR processes in Table II were applied for the amplifications of toxin genes and the presence of amplifications were examined by running them in $2 \%$ of agarose gels (Table II).

\section{Antimicrobial Sensitivity Tests}

Antimicrobial resistance profiles of sorbitol-negative isolates were studied. The susceptibility test was performed according to the Clinical and Laboratory Standards Institute (CLSI)

Table I: Oligonucleotide primers used in the study

\begin{tabular}{lcccc}
\hline Primer & $\begin{array}{c}\text { Target } \\
\text { gene }\end{array}$ & Primer sequence (5'-3') & $\begin{array}{c}\text { Fragment } \\
\text { size (bp) }\end{array}$ & Reference \\
\hline HlyA & hlyA-F & GTA GGG AAG CGA ACA GAG & 361 & Wang et. al., 1997 \\
\hline HlyA & hlyA-R & AAG CTC CGT GTG CCT GAA & 361 & Wang et. al., 1997 \\
\hline Stx1 & stx1-F & ACA CTG GAT GAT CTC AGT GG & 614 & Manna et. al., 2006 \\
\hline Stx1 & stx1-R & CTG AAT CCC CCT CCA TTA TG & 614 & Manna et. al., 2006 \\
\hline Stx2 & stx2-F & CCA TGA CAA CGG ACA GCA GTT & 779 & Manna et. al., 2006 \\
\hline Stx2 & stx2-R & CCT GTC AAC TGA GCA CTT TG & 779 & Manna et. al., 2006 \\
\hline
\end{tabular}


Table II. Thermal cycles for three primers used in the study

\begin{tabular}{lccc}
\hline No & Step & hly-A (E.coli O157:H7) & stx-1 and stx-2 (STEC) \\
\hline 1 & Initial denaturation & $94^{\circ} \mathrm{C} / 4 \mathrm{~min}$. & $94^{\circ} \mathrm{C} / 4 \mathrm{~min}$. \\
\hline \multirow{2}{*}{2} & Denaturation & $94^{\circ} \mathrm{C} / 45 \mathrm{sec}$. & $94^{\circ} \mathrm{C} / 45 \mathrm{sec}$. \\
& Annealing & $61^{\circ} \mathrm{C} / 1 \mathrm{~min} .30 \mathrm{cycle}$ & $61^{\circ} \mathrm{C} / 1 \mathrm{~min} .30 \mathrm{cycle}$ \\
\cline { 2 - 4 } & Extension & $72^{\circ} \mathrm{C} / 1 \mathrm{~min}$. & $72^{\circ} \mathrm{C} / 1 \mathrm{~min}$. \\
\hline 3 & Final extension & $72^{\circ} \mathrm{C} / 7 \mathrm{~min}$. & $72^{\circ} \mathrm{C} / 7 \mathrm{~min}$. \\
\hline 4 & Keeping & $+4^{\circ} \mathrm{C} / \infty$ & $+4^{\circ} \mathrm{C} / \infty$ \\
\hline
\end{tabular}

guidelines. Antimicrobial resistance profiles of sorbitol-negative isolates were studied. The following antibiotics were used: ampicilin $(10 \mu \mathrm{g})$, gentamicin $(10 \mu \mathrm{g})$, cefuroxime $(30 \mu \mathrm{g})$, tetracycline $(30 \mu \mathrm{g})$ and ciprofloxacin $(5 \mu \mathrm{g})$, nalidixic acid $(30 \mu \mathrm{g})$, cotrimoxazole $(25 \mu \mathrm{g})$, and chloramphenicol (30 $\mu \mathrm{g})$ (Oxoid, England). The results were interpreted according to CLSI (2015) criteria (19).

Statistical analysis: All data were evaluated by $\chi 2$ test using Statistical Package for Social Sciences (SPSS1 for Windows V. 17.5, Chicago, USA) software.

\section{Results}

In 150 of the 327 salad samples, significantly E.coli reproduction was determined more than the reference value set by Food Codex, Microbiological criteria. A total of 150 E.coli isolates were tested with sorbitol MacConkey agar and

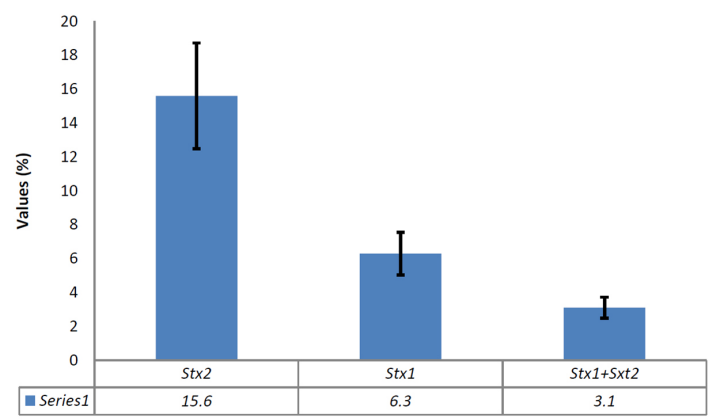

Figure 1. Incidence of shiga toxin genes (stx1 and stx2) in E.coli 0157:H7 isolates.
$32(21.3 \%)$ isolates were sorbitol-negative. Serologically, all of the 32 sorbitol negative isolates were confirmed as serotype O157:H7. Presence of E.coli $\mathrm{O} 157: \mathrm{H} 7$ was confirmed with presence of $h l y-A$ gene of the microorganism. It was found out among the isolates identified as E.coli $\mathrm{O} 157$ : $\mathrm{H} 7$ that $15.6 \%(5 / 32)$ had stx 2 toxin genes, $6.3 \%$ $(2 / 32)$ had stxl toxin genes and 3.1\% (1/32) had both stx 1 and stx 2 toxin genes (Figure 1 and 2).

In our study; $21.3 \%(32 / 150)$ of 150 E.coli isolates isolated from salad samples showed the presence of E.coli O157:H7 with hlyA gene positive and rate of shiga toxin $s t x 2(3.3 \% ; 5 / 150)$ was significantly higher than shiga toxin stxl $(1.3 \%$; $2 / 150),(p<0.05)$. Also; there was an isolate that carried both stx 1 and stx 2 toxin genes $(0.7 \%$; $1 / 150$ ) despite being at low level. When the rate of toxin gene carriage of E.coli $\mathrm{O} 157: \mathrm{H} 7$ isolates was assessed, it was detected that $15.6 \%$ of the isolates carried $s t x 2,6.3 \%$ of isolates carried $s t x 1$

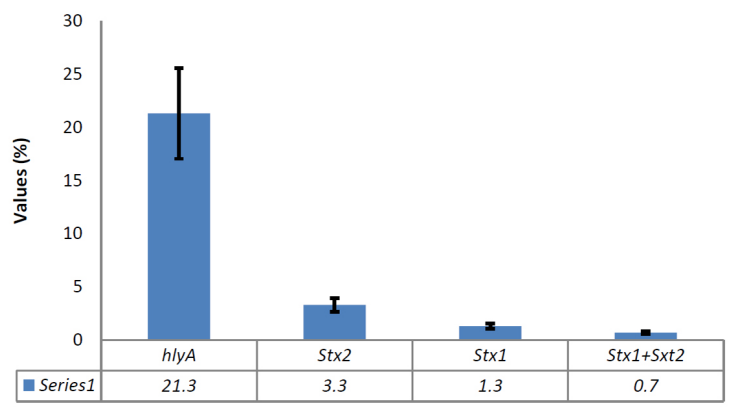

Figure 2. Incidence of hlyA, stx1 and stx2 toxin genes in E.coli isolates. 
toxin genes and rate of isolates being positive in both $s t x l$ and $s t x 2$ toxin genes, was $3.1 \%$.

Following PCR amplifications of $h l y-A$, stx 1 and stx2 genes in E.coli $\mathrm{O} 157: \mathrm{H} 7$ isolates, the PCR products were imaged by running them in $2 \%$ of agarose gels. Electrophoresis images of these genes ( $h l y-A, s t x l$ and $s t x 2)$ are presented below (Figure 3 and 4 ).

Antibiotic sensitivity rates and antibiotic sensitivity distribution of 32 E.coli $\mathrm{O} 157: \mathrm{H} 7$ isolates that were $h l y A$ positive were demonstrated in Table 3.

It was noted that the highest resistance was against ampicillin $(68.8 \% ; 22 / 32)$ while no antimicrobial resistance occurred against cefuroxime and ciprofloxacin. It was detected that all the strains were sensitive against these two antibiotics (cefuroxime and ciprofloxacin). Furthermore, antimicrobial resistance rates against gentamicin and chloramphenicol were determimed as $6.3 \%$

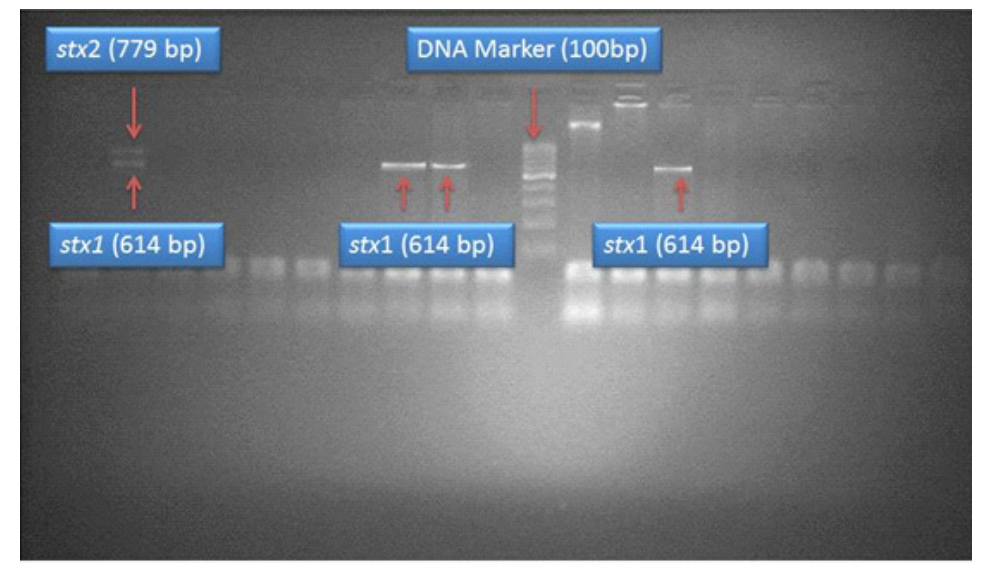

Figure 3. Agarose gel electrophoresis images of PCR amplification products of stx1 (614 bp) and stx2 (779 bp) genes. DNA marker (100 bp ladder) stx1 (614 bp), stx2 (779 bp).

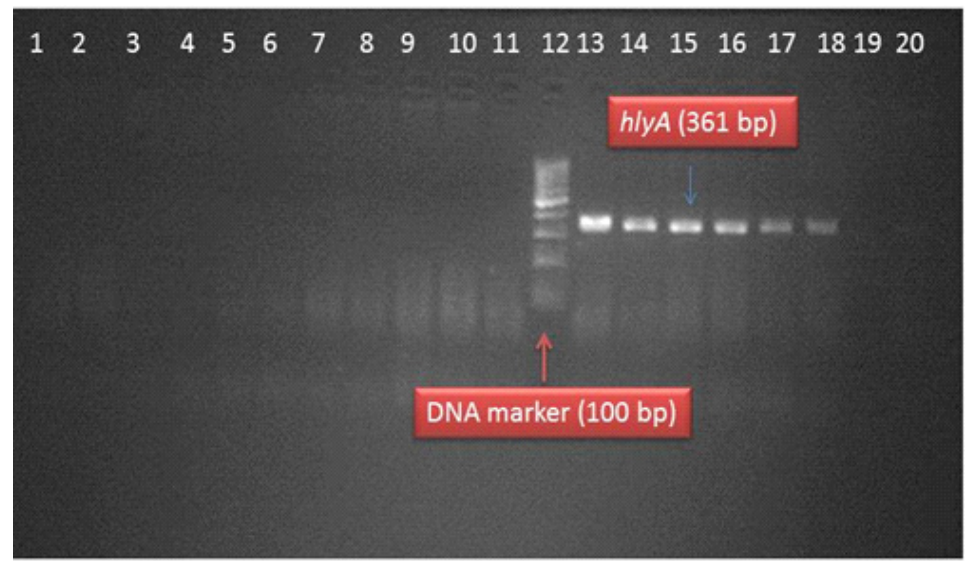

Figure 4. Agarose gel electrophoresis images of PCR amplification products of Hly-A (hemolysin A) gene M: 100 bp DNA Ladder. HlyA (361 bp): 14-18 bands. Negative control: 19. and 20. bands.

Positive control: 13 . band. 
Table III. Antibiotic sensitivity percentages of E.coli 0157:H7 strains that were hlyA positive $(\mathrm{n}=32)$.

\begin{tabular}{lccc}
\hline Antibiotics & $\begin{array}{c}\text { Sensi- } \\
\text { tive }\end{array}$ & $\begin{array}{c}\text { Interme- } \\
\text { diate }\end{array}$ & $\begin{array}{c}\text { Resis- } \\
\text { tant }\end{array}$ \\
\hline Ampiciline & 12.5 & 18.8 & 68.8 \\
\hline Nalidixic Acid & 90.6 & 0 & 3.1 \\
\hline Chloramphenicol & 90.6 & 3.1 & 6.3 \\
\hline Cotrimoxazole & 93.7 & 0 & 3.1 \\
\hline Gentamicin & 93.7 & 0 & 6.3 \\
\hline Tetracycline & 96.9 & 0 & 3.1 \\
\hline Cefuroxime & 100 & 0 & 0 \\
\hline Ciprofloxacin & 100 & 0 & 0 \\
\hline
\end{tabular}

(2/32), while the resistance rates for tetracycline, nalidixic acid and cotrimoxazole were found to be $3.1 \%(1 / 32)$, (Figure 5 ).

In Table IV, antimicrobial drug resistance patterns against ampicilin, gentamicin, cefuroxime, tetracycline, ciprofloxacin, nalidixic acid, cotrimoxazole and chloramphenicol were shown in terms of stxl, stx2 and both stxl and stx2 genes of positive strains of E.coli O157:H7 isolates.

Resistance against ampicillin, gentamicin and chloramphenicol was detected in two of the
E.coli $\mathrm{O} 157: \mathrm{H} 7$ strains (6.3\%) that were positive in stxl gene, while these strains were found to be sensitive to cefuroxime, tetracycline, ciprofloxacin and nalidixic acid and cotrimoxazole. Among five E.coli $\mathrm{O} 157: \mathrm{H} 7$ (15.6\%) that were positive in stx2 gene, one strain of five isolates $(20 \% ; 1 / 5)$ have ampicillin sensitivity but the other four strains $(80 \% ; 4 / 5)$ were found to be ampicillin resistant. However, it was detected that strains that were positive in $s t x 2$ genes were sensitive to all the other antibiotics (gentamicin, cefuroxime, tetracycline, ciprofloxacin, nalidixic acid, cotrimoxazole and chloramphenicol).

It was observed that the antimicrobial resistance profile of one strain $(3.1 \% ; 1 / 32)$ that was positive both in $s t x 1$ and $s t x 2$ genes (\%3.1; $1 / 32$ ) was completely the same as the antimicrobial drug resistance profile of the strain that was positive in stxl toxin only. It was noted that this strain was resistant to ampicillin, gentamicin and chloramphenicol while it was sensitive to all the other tested antibiotics.

\section{Discussion}

Diseases caused by STEC strains are an important public health problem. Although other

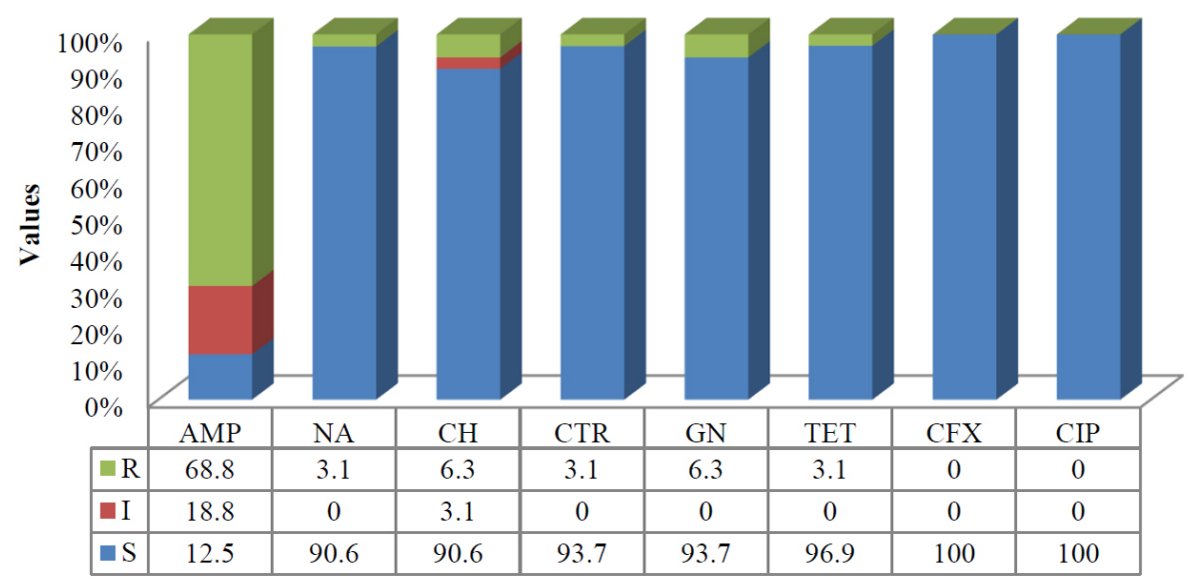

Figure 5. Antibiotic Resistance Patterns of E.coli $0157 \mathrm{H} 7$ isolates. Abbreviations: AMP: Ampicillin; CFX: Cefuroxime; GN: Gentamicin; TE: Tetracyclin; CIP: Ciprofloxacin; NA: Nalidixic acid; CTR: Cotrimoxazole; CH: Chloramphenicol. 
Table IV. Antimicrobial drug resistance patterns in positive E.coli 0157:H7 strains in terms of Shiga toxins.

\begin{tabular}{lcccccccc}
\hline Sample number & CTR & AM & GN & CFM & TE & CIP & CH & NA \\
\hline Stx1 positive & & & & & & & & \\
\hline 1 & $\mathrm{~S}$ & $\mathrm{R}$ & $\mathrm{R}$ & $\mathrm{S}$ & $\mathrm{S}$ & $\mathrm{S}$ & $\mathrm{R}$ & $\mathrm{S}$ \\
\hline 2 & $\mathrm{~S}$ & $\mathrm{R}$ & $\mathrm{R}$ & $\mathrm{S}$ & $\mathrm{S}$ & $\mathrm{S}$ & $\mathrm{R}$ & $\mathrm{S}$ \\
\hline Stx2 positive & & & & & & & & \\
\hline 1 & $\mathrm{~S}$ & $\mathrm{R}$ & $\mathrm{S}$ & $\mathrm{S}$ & $\mathrm{S}$ & $\mathrm{S}$ & $\mathrm{S}$ & $\mathrm{S}$ \\
\hline 2 & $\mathrm{~S}$ & $\mathrm{R}$ & $\mathrm{S}$ & $\mathrm{S}$ & $\mathrm{S}$ & $\mathrm{S}$ & $\mathrm{S}$ & $\mathrm{S}$ \\
\hline 3 & $\mathrm{~S}$ & $\mathrm{~S}$ & $\mathrm{~S}$ & $\mathrm{~S}$ & $\mathrm{~S}$ & $\mathrm{~S}$ & $\mathrm{~S}$ & $\mathrm{~S}$ \\
\hline 4 & $\mathrm{~S}$ & $\mathrm{R}$ & $\mathrm{S}$ & $\mathrm{S}$ & $\mathrm{S}$ & $\mathrm{S}$ & $\mathrm{S}$ & $\mathrm{S}$ \\
\hline 5 & $\mathrm{~S}$ & $\mathrm{R}$ & $\mathrm{S}$ & $\mathrm{S}$ & $\mathrm{S}$ & $\mathrm{S}$ & $\mathrm{S}$ & $\mathrm{S}$ \\
\hline Stx1 and Stx2 positive & & & & & & & & \\
\hline 1 & $\mathrm{~S}$ & $\mathrm{R}$ & $\mathrm{R}$ & $\mathrm{S}$ & $\mathrm{S}$ & $\mathrm{S}$ & $\mathrm{R}$ & $\mathrm{S}$ \\
\hline Total resistance percentages & $100 \%$ & $87.5 \%$ & 0 & 0 & 0 & 0 & 0 & $37.5 \%$ \\
\hline
\end{tabular}

Abbreviations: AMP: Ampicillin; CFX: Cefuroxime; GN: Gentamicin; TE: Tetracyclin; CIP: Ciprofloxacin; NA: Nalidixic acid; CTR: Cotrimoxazole; $\mathrm{CH}$ : Chloramphenicol.

strains of EHEC are frequently reported to be isolated generally in water borne epidemics, it is stated that STEC is the main reason of epidemics in America, Europe and Japan. It is reported that most of the strains of these microorganisms secrete stx2, some of them secrete stx 1 and 2 and a few secrete only stxl (20-22). Most of the strains of these microorganisms secrete stx2, some of them have both stxl and sxt2, and some of them have only stxl secretion.

Stx 1 and stx 2 are the two most important virulence factors for humans. Studies have reported that stx 2 is a more important virulence factor than stx 1 , which is associated with human diseases. It has been reported that $s x t 2$ is more virulent than stxl in animal studies (23).

In our study, the stx 2 gene frequency was found to be $15.6 \%(5 / 32)$ while the stxl toxin gene frequency was $6.3 \%(2 / 32)$ in sorbitol negative E.coli strains. Our findings displayed that 5 of 7 (71.4\%) STEC O157 isolates contained the stx 2 gene. Despite that, only $2(28.6 \%)$ of these isolates contained the stxl gene. Our results seem to be condordant with the literature.
Similar results have been reported from Iran by Akhi et al $(90.9 \%)$, America by Mellor et al. (73\%) and Argentina by Leotta et al. (91\%). These findings indicate that Stx 2 is the most important virulence factor in foodborne STEC O157 infections in Turkey. Therefore, rapid and accurate detection of this toxin (stx2) in food is very important in preventing STEC infections (24-27).

Incidence of E.coli $\mathrm{O} 157: \mathrm{H} 7$ were investigated in various studies in Turkey and a study done in 2013 reported that Escherichia coli O157:H7 was detected in $5(1 \%)$ samples including two diced meat, one minced meat and two raw-milk cheese in 500 samples taken from diced meat, minced meat, burger, raw cow's milk and raw cow's milk cheese. It was seen that 3 of these isolates $(60 \% ; 3 / 5)$ were positive in stx 1 , stx 2 and hly $A$ genes. Interestingly the study indicated that $s t x l$, eaeA and $h l y A$ genes isolated from 2 strains were obtained from raw milk products (16).

In another study done in 2012, E.coli incidence was found to be $36.7 \%$ in such com- 
mercial cheeses consumed in Istanbul as white cheese, tulum cheese, hellim cheese but none demonstrated E.coli O157:H7 (21). Considering the incidence of EHEC in our study to be $21.3 \%$, it is understandable that commercial salads to be consumed are high-risk food for EHEC infections. The study of Bingol et al. indicates that boiled dairy products are among safe products in terms of EHEC (21).

In another study about the frequency of E.coli $\mathrm{O} 157: \mathrm{H} 7$ in meat products in Eastern Anatolia Turkiye, 120 samples of bovine meat, 105 samples of chicken and turkey meat were analyzed and presence of E.coli O157:H7 in bovine meat, chicken and turkey meat were 3.3\%, 1.6\% and $2.7 \%$; respectively (15).

Although it is reported that various contaminated animal products such as bovine meat, milk and dairy products are crucial in disease transmission, it is reported that most of the foodborne epidemic are caused by consumption of lettuce, spinach and other vegetables. According to CDC reports, $41 \%$ of 183 E.coli $\mathrm{O} 157: \mathrm{H} 7 \mathrm{ep}-$ idemic occurring from 1982 to 2002 was caused by steak and $21 \%$ was due to different animal products (26-29).

Consumption of green leafy vegetables has been shown to be one of the most important causes of EHEC (E. coli O157:H7) infections $(30,31)$. In a study done by Wang et al. 2001, it was identified that E. coli $\mathrm{O} 157: \mathrm{H} 7$ is able to survive in rotten parts of green leafy vegetables stored at different temperatures. It was identified that pathogens injected into rotten parts of coriander survived more than four days at 8-15 ${ }^{\circ} \mathrm{C}$ and reproduced at $12{ }^{\circ} \mathrm{C}$. In another study conducted by Allende et al. in 2006; viability of E.coli $\mathrm{O} 157: \mathrm{H} 7$ injected into 6 different fresh plants was analyzed and it was demonstrated that E.coli $\mathrm{O} 157: \mathrm{H} 7$ could survive at $+4{ }^{\circ} \mathrm{C}$ for up to 19 days. Besides, Chauret's study in 2011 detected that 6 EHEC strains with defective $r p o S$ genes became resistant against acidic environ- ment on lettuce leaves when they were stored at $\geq 15^{\circ} \mathrm{C}(32,33)$.

One of the most commonly observed characteristics of E.coli $\mathrm{O} 157: \mathrm{H} 7$ is that it is resistant against low $\mathrm{pH}$ broth and acidic environments that contained $<2 \mathrm{pH}$ values with synthetic gastric juice. This characteristic of E.coli $\mathrm{O} 157: \mathrm{H7}$ results in disease risk among those consuming low $\mathrm{pH}$ products. As emphasized in many studies, this characteristic of E.coli $\mathrm{O} 157: \mathrm{H} 7$ is used to differentiate it from other bacteria living in the microflora $(29,33,34)$.

It was observed that there was not any significant correlation between drug resistance profiles and presence of toxin genes in E.coli $\mathrm{O} 157: \mathrm{H} 7$ strains $(p>0.05)$. Therefore, more comprehensive studies are required to reach a conclusion on this subject.

\section{Conclusion}

In this study, the stx 2 frequency was found to be higher than the stxl frequency. As a result, increased frequency of STEC O157 serotype among foodborne pathogens is a growing public health problem. In light of the study results, it was established that salad samples contained pathogenic E.coli agents that may be dangerous for human health. Because E.coli O157: H7 can lead to serious infections for human health such as hemorrhagic colitis or hemolytic uremic syndrome, we think that cleaning procedures, good manufacturing and storing practices should be established to prevent $\mathrm{O} 157 \mathrm{H} 7$ infection.

Besides this, although resistance to ampicillin in E. coli $\mathrm{O} 157: \mathrm{H} 7$ isolates was found to reach important proportions in the study, resistance rates to other antibiotics were not very high. In developing countries such as Turkey, the fact that $E$. coli $\mathrm{O} 157: \mathrm{H} 7$ reports are very limited indicates the necessity of examining this pathogen in more detail. Thus, it is thought that significant epidemiological data can be obtained for our country. 


\section{Acknowledgment}

This work was supported by the Research Fund of Mustafa Kemal University. This study has been in accordance with both legal and ethical grounds.

\section{Conflict of interest}

No conflict of interest to declare.

\section{References}

1. Nawas T, Mazumdar RM, Das S, Nipa MN, Islam S, Bhuiyan HR, et al. Microbiological Quality and Antibiogram of E. coli, Salmonella and Vibrio of Salad and Water from Restaurants of Chittagong. J. Environ. Sci. \& Natural Resources 2012;5(1):159-66. DOI: 10.3329/ jesnr.v5i1.11571

2. Pennington $H$. Escherichia coli O157. Lancet 2010;376(9750):1428-35. DOI: 10.1016/S01406736(10)60963-4

3. Witold AF, Carolyn JH. Escherichia coli O157:H7: Animal Reservoir and Sources of Human Infection. Foodborne Pathog Dis. 2011;8(4):465-87. DOI: 10.1089/ fpd.2010.0673

4. Marder EP, Garman KN, Ingram LA, Dunn JR. Multistate Outbreak of Escherichia coli O157:H7 Associated with Bagged Salad. Foodborne Path. Dis. 2014; 11(8):593-5. DOI: 10.1089/fpd.2013.1726

5. Baker CA, Rubinelli PM, Park SH, Carbonero F, Ricke SC. Shiga toxin-producing Escherichia coli in food: Incidence, ecology, and detection strategies. Food Control 2016; 59:407-19. DOI: 10.1016/j.foodcont.2015.06.011

6. Bentancor A, Rumi MV, Carbonari C, Gerhardt E, Larzábal M, Vilte DA, et al. Profile of shiga toxin-producing Escherichia coli strains isolated from dogs and cats and genetic relationships with isolates from cattle, meat and humans. Vet Microbiol. 2012; 156; (3-4): 336-342. DOI: 10.1016/j.vetmic.2011.10.030

7. Gordillo R, Cordoba JJ, Andrade MJ, Luque MI, Rodríguez M. Development of PCR assays for detection of Escherichia coli O157:H7 in meat products. Meat Sci 2011;88(4):767-73. DOI: 10.1016/j.meatsci.2011.03.011

8. Bandyopadhyay S, Lodh C, Rahaman H, Bhattacharya
D, Bera AK, Ahmed FA, et al. Characterization of shiga toxin producing (STEC) and enteropathogenic Escherichia coli (EPEC) in raw yak (Poephagus grunniens) milk and milk products. Res Vet Sci. 2012;93(2):60410. DOI: 10.1016/j.rvsc.2011.12.011

9. Russo LM, Melton-Celsa AR, Smith MJ, O'Brien AD. Comparisons of native Shiga toxins (Stxs) type 1 and 2 with chimeric toxins indicate that the source of the binding subunit dictates degree of toxicity. PLoS One 2014;9:e93463. DOI: 10.1371/journal.pone.0093463

10. Chaves BD, Echeverry A, Miller MF, Brashears MM. Prevalence of molecular markers for Salmonella and Shiga toxigenic Escherichia coli (STEC) in whole-muscle beef cuts sold at retail markets. Food Control 2015;50:497-501. DOI: 10.1016/j.foodcont.2014.09.024

11. Su H, Ma Q, Shang K. Gold nanoparticles as colorimetric sensor: A case study on E. coli O157:H7 as a model for Gram-negative bacteria. Sensor Actuat B-Chem 2012;161:298-303. DOI: 10.1016/j.snb.2011.10.035

12. Bandyopadhyay S, Lodh $\mathrm{C}$, Rahaman $\mathrm{H}$, Bhattacharya D, Bera AK, Ahmed FA, et al. Characterization of shiga toxin producing (STEC) and enteropathogenic Escherichia coli (EPEC) in raw yak (Poephagus grunniens) milk and milk products. Res Vet Sci. 2012;93(2):60410. DOI: 10.1016/j.rvsc.2011.12.011

13. Russo LM, Melton-Celsa AR, Smith MJ, O’Brien AD. Comparisons of native Shiga toxins (Stxs) type 1 and 2 with chimeric toxins indicate that the source of the binding subunit dictates degree of toxicity. PLoS One 2014;9:e93463. DOI: 10.1371/journal.pone.0093463

14. Bai J, Shi X, Nagaraja TG. A multiplex PCR procedure for the detection of six major virulence genes in Escherichia coli O157:H7. J Microbiol Methods, 2010; 82: 85-9. DOI: 10.1016/j.mimet.2010.05.003

15. Unsal C. Occurance E.coli O157: H7 in meat consumed in Erzurum. Thesis, Ataturk University, 2007.

16. Ertas N, Gonulalan Z, Yildirim Y, Karadal F, Abay S, Al S. Detection of Escherichia coli O157:H7 using immunomagnetic separation and mPCR in Turkish foods of animal origin. Lett Appl Microbiol. 2013;57(4):373-9.

17. https://www.fda.gov/Drugs/GuidanceComplianceRegulatoryInformation/Guidances/default.htm.

18. Pizarro MA, Orozco JH, Degarbo SM, Calderon AE, Nardello AL, Laciar A, et al. Virulence profiles of Shiga Toxin-Producing Esch $\neg$ erichia coli and other potentially diarrheagenic E.coli of bovine origin, in Mendo- 
za, Argentina. Braz J Microbiol. 2013;44(4):1173-80. DOI: $10.1590 / \mathrm{S} 1517-83822014005000010$

19. Clinical and Laboratory Standards Institute. Performance standarts for Antimicrobial Susceptibility Testing; Twenty-Fifth Informational Supplement, M02-A12, M07-A10 and M11-A8, 2015.

20. Trevisani M, Mancusi R, Delle Donne G, Bacci C, Bassi L, Bonardi S. Detection of Shiga toxin (Stx)-producing Escherichia coli (STEC) in bovine dairy herds in Northern Italy. Int. J. Food Microbiol. 2014;184:45-9. DOI: 10.1016/j.ijfoodmicro.2013.12.033

21. Edelstein M, Sundborger C, Hergens MP, Ivarsson S, Dryselius R, Insulander M, et al. Barriers to Trace-back in a Salad-associated EHEC Outbreak, Sweden, June 2013. PLoS Currents 2014. DOI: 10.1371/currents.outbreaks.80bbab3af3232be0372ea0e904dcd1fe

22. Bingol EB, Colak H, Hampikyan H. Presence of enterotoxin and verotoxin inTurkish cheeses sold in Istanbul. Turk J Vet Anim Sci, 2012;36(4):424-32.

23. Kesava Naidu G, RGN GSM, Shivannavar CT. Detection of Shiga toxin genes (stx1 \& stx2) and molecular characterization of shiga-toxigenic Escherichia coli isolated from divers sources in Gulbarga region, India. Pharmacophore, 2011;2(5):253-65.

24. Akhi MT, Ostadgavahi AT, Ghotaslou R, Asgharzadeh M, Pirzadeh T, Sorayaei Sowmesarayi V, Memar MY. Detection, Virulence Gene Assessment and Antibiotic Resistance Pattern of O157 Enterohemorrhagic Escherichia coli in Tabriz, Iran. Jundishapur J Microbiol. 2015;8(11):e2. DOI: 10.5812/jjm.25317

25. Mellor GE, Besser TE, Davis MA, Beavis B, Jung W, Smith HV, et al. Multilocus genotype analysis of Escherichia coli $\mathrm{O} 157$ isolates from Australia and the United States provides evidence of geo $\neg$ graphic divergence. Appl Environ Microbiol. 2013;79(16):5050-8. DOI: 10.1128/AEM.01525-13

26. Vicentei HIG, do AmaralI LA, Cerqueira AMF. Shigatoxigenic Esch $\neg$ erichia coli serogroups O157, O111 and $\mathrm{O} 113$ in feces, water and milk samples from dairy farms. Braz J Microbiol. 2005; 36(3):217-22. DOI: 10.1590/S1517-83822005000300003

27. Leotta GA, Miliwebsky ES, Chinen I, Espinosa EM, Azzopardi K, Tennant SM, et al. Characterisation of Shiga toxin-producing Escherichia coli O157 strains isolated from humans in Argentina, Australia and New Zealand. BMC Microbiol. 2008;8:46. DOI: 10.1186/1471-2180$8-46$

28. O'Brien M, Hunt K, McSweeney S, Jordan K. Occurrence of foodborne pathogens in Irish farmhouse cheese. Food Microbiol 2008;26:910-4. DOI: 10.1016/j. fm.2009.06.009

29. CDC, 2016; https://www.cdc.gov/ecoli/2016/o12106-16/. Multistate Outbreak of Shiga toxin-producing Escherichia coli Infections (Final Update), 2016.

30. Berger CN, Sodha SV, Shaw RK, Griffin PM, Pink D, Hand P, et al. Freshfruit and vegetables as vehicles for the transmission of human pathogens. Environ Microbiol 2010;12:2385-97. DOI: 10.1111/j.14622920.2010.02297.x

31. Wang H, Feng H, Luo Y. Microbial reduction and storage quality of fresh-cut cilantrowashed with acidic electroyzed water and aqueous ozone. Food Res Int 2004;37:949-56. DOI: 10.1016/j.foodres.2004.06.004

32. Allende A, McEvoy J, Tao Y, Luo Y. Antimicrobial effect of acidified sodium chlorite, sodium chlorite, sodium hypochlorite and citric acid on Escherichia coli O157:H7 and naturalmicroflora on fresh-cut cilantro. Food Control 2009;20:230-4. DOI: 10.1016/j.foodcont.2008.05.009

33. Chauret C. Survival and control of Escherichia coli $\mathrm{O} 157: \mathrm{H} 7$ in foods, beverages, soil and water. Virulence. 2011;2(6):593-601. DOI: 10.4161/viru.2.6.18423

34. http://www.foodsafety.govt.nz/elibrary/industry/E.coli-Organism_Invades.pdf. E. coli O157:H7, accessing date 27.02.2017. 